\title{
The Effect of Open-Ended High Tunnels in Western Washington on Late Blight and Physiological Leaf Roll Among Five Tomato Cultivars
}

\author{
M. Powell, B. Gundersen, J. Cowan, C. A. Miles, and D. A. Inglis, Northwestern Washington Research and Extension Center, Wash- \\ ington State University-Mount Vernon 98273-9761
}

\begin{abstract}
Powell, M., Gundersen, B., Cowan, J., Miles, C. A., and Inglis, D. A. 2014. The effect of open-ended high tunnels in western Washington on late blight and physiological leaf roll among five tomato cultivars. Plant Dis. 98:1639-1647.

A 3-year study in western Washington from 2010 to 2012 evaluated five tomato cultivars for tomato disease development and yield in open-ended high-tunnel versus open-field settings. Findings in 2010 revealed that severity of late blight, caused by Phytophthora infestans (US-11), was significantly $(P=0.002)$ lower in high-tunnel compared with open-field experimental plots based on area under disease progress curve (AUDPC) values of 0.02 versus 321, respectively. In spite of rescue foliar fungicide applications to open-field plots in 2011 and 2012, the mean number of late blight infections across cultivars was 1.8 to 30.8 compared with only 0 to 6.5 in high tunnels for these years. Furthermore, accumulated hours of leaf wetness were fewer in high tunnels than the open field each year (857 versus 1,060 in 2010,598 versus 998 in 2011, and 885 versus 923 in 2012). Cultivar susceptibility to late blight could not be differentiated in high tunnels due to low disease pressure. However, all five cultivars proved susceptible in the open field, with 'Oregon Spring' consistently having the most lesions. In contrast, high-tunnel production contributed to an increased severity

of physiological leaf roll compared with open-field production each year, and these values differed significantly $(P=0.0335$ and 0.0252$)$ in 2011 and 2012, respectively. AUDPC values for physiological leaf roll showed that Oregon Spring was significantly $(P=<0.0001)$ less susceptible than other cultivars each year. Physiological leaf roll correlated positively ( $r$ values of 0.758 to 0.960$)$ and significantly $(P<$ $0.05)$ with leaf wetness and air temperature in all years in both hightunnel and open-field settings but the same was not true for relative humidity. Even with severe physiological leaf roll, high-tunnel production in 2010 resulted in significantly $(P<0.0001)$ greater total tomato yield than open-field production (35.0 versus $\left.10.6 \mathrm{t} \mathrm{ha}^{-1}\right)$. Although a significant interaction between production system and cultivar occurred in 2011 and 2012, tomato yield always was greater in hightunnel than open-field plots. Open-ended high tunnels offer tomato growers a potential tool for managing late blight in western Washington while also increasing yield, and could be especially useful in organic production.
\end{abstract}

Tomato fruit (Solanum lycopersicum, syn. Lycopersicon esculentum Mill.) are produced primarily for fresh market sales in western Washington. This niche market exists due to the region's large urban population and high demand for locally grown and organic vegetables (16). The climate in western Washington generally is cool, ranging from 15 to $17^{\circ} \mathrm{C}$ on average during the tomato growing season months of June to September (42). Given that the optimum temperatures for growing tomato are between 25 and $30^{\circ} \mathrm{C}$ (34), protective structures such as greenhouses are required for successful commercial production. However, greenhouse tomato production can be expensive because of the fixed costs associated with heating, ventilating, and lighting $(52,60)$. In contrast, hightunnel systems have lower construction costs and inputs compared with greenhouse production (64). Because small farms and organic vegetables constitute a growing segment of western Washington agriculture, high tunnels present a new opportunity for growing tomato economically in the region (15).

A high tunnel is a temporary structure composed of a hoop frame covered with clear polyethylene constructed atop native soil, and is passively heated and ventilated (38). Solar energy accumulates as heat inside high tunnels due to restricted air flow and the reflection of long-wave radiation within the plastic cover. Consequently, the covers can increase heat units $(60,61)$ and provide frost protection $(50,59)$, thereby extending the growing season and increasing fruit yield $(9,18,51,59,60,62)$. An open-ended high tunnel is one in which there are no end walls; for some models, venting can be augmented further by raising and lowering the side walls.

Corresponding author: M. Powell, E-mail: Marianne.powell@wsu.edu

Accepted for publication 12 May 2014.

http://dx.doi.org/10.1094/PDIS-12-13-1261-RE

(c) 2014 The American Phytopathological Society
Late blight, caused by Phytophthora infestans (Mont.) de Bary, threatens tomato production in western Washington field settings, greenhouses, and home gardens alike. The cool coastal climate is conducive to annual disease outbreaks and late blight has been especially problematic on organically grown tomato, where the only approved fungicides are mostly copper based (54). Relative to many other fungicides, copper fungicides can have limited efficacy in late blight control (27). In 2009, a late blight pandemic occurred in the northeastern and southeastern United States as a result of spread from diseased tomato transplants $(13,23)$. Organic growers experienced greater yield loss than the conventional growers who were able to utilize non-copper-based fungicides (13). Many strains of $P$. infestans that are highly aggressive on tomato exist and newly recognized strains can be introduced periodically into production regions $(21,23,40,58)$. Adequate host resistance in tomato cultivars is not available due, in part, to the sporadic emergence of new isolates of $P$. infestans $(43,44)$.

One potential new cultural practice for controlling tomato late blight in western Washington is the use of open-ended high tunnels, which would allow for passive ventilation and protection from rains as the means to reduce leaf wetness, a major factor contributing to disease outbreaks $(3,5)$. In various situations, high tunnels have limited the incidence and severity of late blight in some tomato-producing areas, even on susceptible cultivars $(29,31,36,55)$. High tunnels also have reduced the severity of epidemics of Botrytis fruit rot on strawberry $(30,67)$. However on some vegetable crops in high tunnels, gray mold can be problematic $(2,48,62)$. Other diseases such as leaf mold (1) and powdery mildew $(2,62,67)$ may be more severe in high tunnels when the particular environmental conditions that favor them occur inside the structures.

Tomato is the most common vegetable produced under high tunnels in the United States $(7,38)$. Often, in high tunnels, black polyethylene mulch is laid over planting beds to provide weed control in lieu of herbicides, and also to warm the soil (37). Because most 
herbicides are not approved for organic production $(8,33)$, the mulch offers organic growers an effective weed control alternative. One problem, though, which can occur on tomato in western Washington specifically and the Pacific Northwest in general is physiological leaf roll (46). This disorder affects many tomato cultivars but it is unclear whether it causes reduction in yield. Although the etiology has not been elucidated clearly, there is speculation that excess light exposure, soil moisture, prolonged high temperatures, growth habit, or pruning are predisposing factors $(46,47,63,65)$. Physiological leaf roll also could be cultivar dependent and not solely an outcome of determinate versus indeterminate growth habit (25). Management recommendations for physiological leaf roll include planting determinate cultivars in well-drained soils (46) and limiting pruning (57). Some high tunnels could potentially affect the severity of physiological leaf roll because the plastic covering reduces solar radiation transmission according to the thickness (60) and slope (19) of the frame. Outside of a few short reports $(22,25,28,29,31)$, high-tunnel production has not been examined for effects on late blight or physiological leaf roll of tomato under the climatic conditions of the coastal Pacific Northwest. The purpose of this study was to investigate the progression of naturally occurring late blight outbreaks and physiological leaf roll, and compare yield among five tomato cultivars in high-tunnel and open-field production systems in western Washington.

\section{Materials and Methods}

Field study. A 3-year field study was set-up at Washington State University's Northwestern Washington Research \& Extension Center near Mount Vernon during the 2010-12 growing seasons in a field that had been managed organically since 2006 . Four hightunnel plots (an open-ended, three-season structure; model Solo; Haygrove Ltd.) measuring $37 \mathrm{~m}$ long by $8 \mathrm{~m}$ wide by $3 \mathrm{~m}$ high were constructed upon Skagit silt loam, a poor-draining soil $30 \mathrm{~cm}$ in depth with layers of silty loam, silty clay loam, and very fine sandy loam (45). Four open-field plots of corresponding dimension also were established, and managed similarly. Plots were arranged according to a randomized complete block, split-plot design. The main plots (high tunnel and open field) were assigned randomly to the field in the first year but remained at the same location during each of the 3 years; the tomato cultivar subplots were rerandomized each year. Following plowing and rototilling, soil was amended with organic fertilizer on 29 April 2010, 3 May 2011, and 23 April 2012 to achieve 89, 26, and $61 \mathrm{~kg}$ of N, P, and K, respectively, per hectare. PAR4 9-3-7 (North Pacific Ag Products) was

Table 1. Tomato cultivars selected for an open-ended high-tunnel production study in western Washington, 2010 to 2012

\begin{tabular}{llcc}
\hline & \multicolumn{3}{c}{ Description } \\
\cline { 2 - 4 } Cultivars & Growth habit & Days to maturity & Type \\
\hline Test & & \\
Celebrity, $\mathrm{t}$ & Determinate & 72 & F1 hybrid \\
Cherokee Purple $^{\mathrm{u}, \mathrm{v}}$ & Indeterminate & 72 & Heirloom \\
Early Girl $^{\mathrm{s}, \mathrm{w}}$ & Determinate & 65 & F1 hybrid \\
Oregon Spring $^{\mathrm{s}}$ & Determinate & $75-80$ & Heirloom \\
Stupices $^{\mathrm{s}}$ & Indeterminate & $60-65$ & Heirloom \\
Observational $^{\mathrm{x}}$ & & & \\
Red Brandywine $^{\mathrm{y}}$ & Indeterminate & 75 & Heirloom \\
Defiant $^{\mathrm{v}}$ & Determinate & 70 & F1 hybrid \\
Glacier $^{\mathrm{s}}$ & Determinate & 55 & Heirloom \\
Red Defender $^{\mathrm{z}}$ & Determinate & 75 & F1 hybrid \\
\hline
\end{tabular}

${ }^{s}$ Seed supplied by Territorial Seed Company (Cottage Grove, OR).

${ }^{t}$ Seed supplied by Harris Seed (Rochester, NY).

" Seed supplied by Seed Way LLC (Elizabethtown, PA).

v Seed supplied by Johnny's Selected Seed (Waterville, ME).

" Seed supplied by Park Seed (Greenwood, SC).

${ }^{x}$ Cultivars Red Brandywine, Defiant, and Glacier with Red Defender planted only in 2010,2011 , or 2012 , respectively, to observe potential resistance to late blight.

${ }^{y}$ Seed Way LLC (Elizabethtown, PA).

${ }^{\text {z }}$ Harris Moran Seed Co. (Modesto, CA). used in 2010 and 2011 and Proganic 8-2-4 (Wilbur Ellis) was used in 2012. Raised beds ( $37 \mathrm{~m}$ long by $0.9 \mathrm{~m}$ wide by $0.2 \mathrm{~m}$ high) were shaped with a tractor (Model 2600 Raised Bed Mulch Layer; Rain-Flo Irrigation) and, simultaneously, low-flow drip tape (1.6 $\mathrm{cm}$ in diameter, $0.2 \mathrm{~mm}$ thick, and $20-\mathrm{cm}$ emitter spacing; John Deere Water) and black polyethylene mulch (0.03-mm-thick embossed; Berry Plastics Corporation) were laid over the beds and secured with soil on the same dates, following fertilizer incorporation. The five tomato cultivars chosen for the study were early to midseason maturity, had organic seed availability, or are reported as cold tolerant or disease resistant (Table 1). Additional replicated plots of four other cultivars were included in some years (Table 1) to observe reactions to late blight under western Washington conditions. Each tomato cultivar was hand transplanted into subplots measuring $4.3 \mathrm{~m}$ long by $0.9 \mathrm{~m}$ wide by $0.2 \mathrm{~m}$ high. Seven 6 -weekold seedlings per cultivar were transplanted $61 \mathrm{~cm}$ apart on 27 May and 3 June 2010, 12 and 31 May 2011, and 21 and 30 May 2012 for the high-tunnel and open-field blocks, respectively. Holes for transplanting were cut into the black plastic using a 10-cm-diameter bulb planter. Any dead seedlings resulting from mechanical injury were replaced up to 4 weeks after transplanting but not thereafter, because later-planted transplants would not have had sufficient time to recover and grow comparably with surrounding plants. Irrigation began at transplanting and continued until the end of each growing season at a rate of $1.2 \mathrm{~cm} /$ week in 2010,2011, and 2012, except from 5 August until the end of the growing season in 2012, when plants received $1.0 \mathrm{~cm} /$ week and plots were drip fertilized (Acadian Marine Extract Powder 1-1-17, Acadian Agritech; and BioLink 6-0-0, Westbridge Agricultural Products) weekly, with each product at $1 \mathrm{~kg} / \mathrm{ha}$. Beginning approximately 2 to 3 weeks after transplanting, when plant heights reached 30 to $38 \mathrm{~cm}$, beds were staked and plants were trellised using a Florida weave system (66). Plants were pruned weekly to remove lateral branches, leaving one to two central leaders. Weeds emerging in the planting holes were removed by hand and weeds between bed rows were removed with a hoe once a week. Insecticides approved for use in certified organic production were applied each year for the control of flea beetle, aphid, and thrips (Table 2). Late blight fungicide applications (Table 2) had to be made each year to protect tomato yield data. The fungicides used were approved for tomato production by the Organic Materials Review Institute except the products used for the last two applications in 2012 (open-field plots only). Those fungicides were selected due to the threat of a severe late blight epidemic, because early onset of the disease had been reported throughout the region. Harvest dates for high-tunnel plots were 5 August to 19 October 2010, 12 August to 19 October 2011, and 6 August to 8 October 2012. Harvest dates for open-field plots were 12 August to 5 October 2010, 19 August to 19 October 2011, and 20 August to 4 October 2012. Tomato fruit were harvested by hand once to twice per week as needed when fruit were $75 \%$ red, which equates to "light red" or "stage 5" and is based on how each cultivar ripens. For example, 'Oregon Spring' is harvested when shoulders are $25 \%$ non-red, whereas 'Stupice' is picked after the tomato becomes light red or dark pink throughout. In 2010, fruit marketability was assigned according to United States Department of Agriculture (USDA) Grade 1, an export standard. In 2011 and 2012, marketability assessments were changed to USDA Grade 2, a direct market standard, to more accurately reflect what tomato growers in western Washington are commonly adapting for fresh-market sales.

Disease assessments and pathogen identification. All cultivars were evaluated during the growing season for naturally occurring diseases as well as for tomato disorders. Weekly disease ratings were done by assessing severity of diseased plants visually as percent plant tissue affected per subplot. Rating dates were 9 July to 27 September 2010, 8 June to 4 October 2011, and 28 June to 21 September 2012. For late blight, symptoms included sunken and dark-green lesions on leaves, with white sporulation primarily observed on the abaxial side; black and firm elongated lesions on the stem; and bronze-colored sunken lesions on fruit. In 2010 , 
severity of late blight was estimated as the percentage of each plot affected on each rating date; these data were used to calculate area under disease progress curve (AUDPC) values. However, in 2011 and 2012, the rating system had to be changed in order to minimize the amount of blighted fruit and secure representative fruit yield per other project requirements. Thus, to delay the progress of the epidemic and limit the number of potential blighted fruit, all tomato tissues affected by late blight first were counted weekly or biweekly, depending on the rate of disease spread, and then all affected tissues were removed with pruning shears (treated with $70 \%$ ethanol after each removal). Each time a trifoliate leaf or leaves with adjoining petiole or stems was removed, the area was counted as one "infection". Thus, cultivar comparisons were by the mean number of infections that were removed, from the total number recorded over the entire season. Incidence of blighted fruit was recorded on a per-fruit basis, 2010 to 2012.

Isolates of $P$. infestans were recovered from samples of tomato leaves, stems, and fruit with symptoms of late blight. Affected plant tissues were placed in a moist chamber and sporangia were collected on sterilized filter paper strips and transferred to rye $\mathrm{B}$ agar (12), then incubated at $16^{\circ} \mathrm{C}$ in the dark. Isolates recovered during the 2010 growing season were identified using an allozyme genotype assay as described by Goodwin et al. (20). Isolates from the 2011 and 2012 growing seasons were sent to the Fry Laboratory at Cornell University for genotype characterization (39).

Symptoms of physiological leaf roll included stiff leaves with upward rolled margins, which appeared first on lower leaves, then progressed acropetally. Physiological leaf roll was rated visually on the same rating dates as for late blight and on a percentage basis per plot so that AUDPC values could be calculated.

Environmental monitoring. Environmental data for air temperature, leaf wetness, precipitation, and relative humidity were collected in 15-min intervals with a weather station (Hobo; Onset Computer) located in one high-tunnel and one open-field replicate from 3 June to 27 September 2010, 31 May to 20 September 2011, and 30 May to 13 September 2012. Each year, the open-ended high tunnels allowed for passive air flow and, on warm, sunny days when temperatures exceeded $27^{\circ} \mathrm{C}$, the sidewalls were raised to allow cross ventilation.

Data analysis. Final percent late blight and AUDPC values acquired in 2010 were subjected to analysis of variance using the PROC GLM procedure of SAS (v. 9.2; SAS Institute Inc.). Fisher's protected least significant difference was used to obtain mean separations. Due to the removal of blighted tomato tissues in 2011 and 2012, values for mean number of infections had to be used instead for making comparisons. These were rank transformed and analyzed nonparametrically using PROC GLM. AUDPC values for physiological leaf roll were subjected to analysis of variance using PROC MIXED according to the Satterthwaite method (53) for assessing degrees of freedom. Correlation analysis (PROC CORR) was performed using percent late blight (2010) and physiological leaf roll (all years) weekly severity ratings, and average air temperature, leaf wetness, and relative humidity recordings. Yield data were analyzed using PROC MIXED, with the Kenward-Roger method to determine denominator degrees of freedom for $F$ tests. An interaction between production system and cultivar was detected for total and marketable tomato yield in 2011 and 2012; thus, yields are presented by production system. Least squared means were used to obtain mean separations. Where the data did not satisfy assumptions of normality and equal variance for analysis of variance, transformations were selected using the range method described by Kirk (35); all transformed data then met assumption criteria for analysis of variance.

\section{Results}

Disease assessments and characterization of $\boldsymbol{P}$. infestans. Late blight and physiological leaf roll were observed annually and were the primary problems detected on the tomato cultivars in all years. For late blight, naturally occurring outbreaks were observed 7, 11, and 0 days later in high-tunnel than open-field plots over the 3 years (i.e., 2 September versus 26 August 2010, 13 September versus 2 September 2011, and 26 July 2012, respectively). The epidemics were categorized as late onset with moderate disease in 2010 and 2011 and early onset with severe disease initially but low disease late season in 2012.

Table 2. Insecticide and fungicide applications to tomato in high-tunnel (HT) and open-field (OF) production systems, 2010 to 2012

\begin{tabular}{|c|c|c|c|c|c|c|}
\hline Year $^{9}$ & Problem & Product applied $^{\mathrm{r}}$ & Rate $\left(\mathrm{kg} \mathrm{ha}^{-1}\right)^{\mathrm{s}}$ & Dates applied & HT & OF \\
\hline 2010 & Flea beetle & Entrust Naturalyte Insect Control ${ }^{t}$ & 0.1 & 18 June & + & + \\
\hline 2011 & Flea beetle & PyGanic Crop Protection EC $5.0 \mathrm{ii}^{\mathrm{u}}$ & 0.1 & 11 July & + & + \\
\hline 2010 & Aphids & PyGanic Crop Protection EC 5.0 ii & 4.9 & 11 June and 4 August & + & $\ldots$ \\
\hline 2010 & Aphids & PyGanic Crop Protection EC 5.0 ii & 4.9 & 11 June & $\ldots$ & + \\
\hline 2011 & Aphids & Entrust Naturalyte Insect Control & 0.2 & 8 August & + & + \\
\hline 2012 & Aphids & PyGanic Crop Protection EC 5.0 ii & 9.1 & 23 July and 4 September & + & + \\
\hline 2010 & Thrips & Entrust Naturalyte Insect Control & 0.1 & 9 July & + & + \\
\hline 2012 & Thrips & Entrust Naturalyte Insect Control & 0.2 & 23 July & + & + \\
\hline 2010 & Late blight & Agri Star Nucop $50 \mathrm{WP}^{\mathrm{v}}$ & 3.5 & 20 August and 3 September & + & + \\
\hline 2011 & Late blight & Nordox $75 \mathrm{WG}^{\mathrm{w}}$ & 2.2 & 22 July & $\ldots$ & + \\
\hline 2011 & Late blight & Agri Star Nucop 50 WP & 3.5 & 11 and 26 August, 1,7 , and 14 September & $\ldots$ & + \\
\hline 2012 & Late blight & Agri Star Nucop $50 \mathrm{WP}$ & 3.5 & 27 June and 16 July ${ }^{x}$ & + & + \\
\hline 2012 & Late blight & *Bravo Weather Stik $/ *$ Curzate $60 \mathrm{DF}^{\mathrm{z}}$ & 1.7 liters $/ 0.2$ & 27 July and 3,10 and 17 August & $\ldots$ & + \\
\hline 2012 & Late blight & *Bravo Weather Stik & 1.7 liters & 24 August & $\ldots$ & + \\
\hline
\end{tabular}

${ }^{\mathrm{q}}$ In 2010, all applications were made with a CP3 back pack sprayer (Cooper Pegler, UK) and a TeeJet flat spray tip (8004VS) nozzle (TeeJet Technologies, Carol Stream, IL) at 25 psi; and in 2011 and 2012, all applications were made with a Bolens 1556 Hydrostatic tractor (MTD Products, Cleveland, OH) and a pull tank (Demco, Boyden, IA) at 30 psi with only one exception (i.e., on 27 July 2012), late blight fungicides were applied with a CP3 back pack sprayer.

${ }^{\mathrm{r}}$ Asterisk (*) indicates that applied product was not allowed for use in certified organic production according to the Organic Materials Review Institute but was used for emergency disease control on the organically-managed land during periods of high disease pressure.

${ }^{\mathrm{s}}$ Insecticide and fungicide applications were diluted in 132 to 189 liters of water.

${ }^{t}$ Entrust Naturalyte Insect Control (active ingredient spinosad; Dow AgroSciences LLC, Indianapolis, IN) allowed for use in certified organic production.

" PyGanic Crop Protection EC 5.0 ii (active ingredient pyrethrins; McLaughlin Gormley King Co., Minneapolis, MN) allowed for use in certified organic production.

$\checkmark$ Agri Star Nu Cop 50 WP (active ingredient copper hydroxide; Albaugh Inc., Akeney, IA) allowed for use in certified organic production.

${ }^{\text {w Nordox }} 75$ WG (active ingredient cuprous oxide; Nordox AS, Oslo, Norway) was sprayed for fungicide rotation, and is allowed for use in certified organic production.

x Agri Star Nucop 50 WP only was applied in the high tunnels on 27 June in 2012.

y Bravo Weather Stik (active ingredient chlorothalonil; Syngenta Crop Protection LLC, Greensboro, NC).

${ }^{\mathrm{z}}$ Curzate 60DF (active ingredient cymoxanil; DuPont, Wilmington, DE). 
Late blight proved to be the most severe in the open-field plots in 2010, when sanitation measures were not taken, which allowed for recurrent sporulation and disease spread (Fig. 1). Two late blight fungicides were applied similarly to high-tunnel and openfield plots in an attempt to slow the progress of the epidemic (Table 2). Even so, final percent foliar late blight and AUDPC values were significantly $(P=0.0024$ and $P<0.0001$, respectively) less for the high-tunnel compared with the open-field production system (0.002 and 37.8\%; 0.02 and 321, respectively) (Table 3). In 2011 and 2012, when rigorous sanitation measures were employed in all plots and infected tissues deliberately removed in an attempt to slow the epidemic and protect fruit yield, the mean number of late blight infections across all cultivars over the entire growing season still was less in the high tunnels compared with the open field, and ranged from 0 to 6.5 compared with 1.8 to 30.8 , respectively. Late blight again had to be managed with fungicide applications both years. Only one application was made in high tunnels in 2012, whereas six and seven fungicide applications were made in the open field in 2011 and 2012, respectively (Table 2). Despite aggressive control efforts, late blight continued to be more severe in the open field compared with the high tunnels. Also, during peak disease periods (6 to 13 September 2011 and 2 to 7 August 2012), mean number of late blight infections was higher for plants in the open field than for plants in the high tunnels (Fig. 2).

Because late blight pressure was low and disease severity was similar among all cultivars in the high tunnels, designation of cultivar susceptibility was based on disease ratings (AUDPC values in 2010, and mean number of late blight infections in 2011 and 2012) acquired in the open field. Oregon Spring was the most susceptible cultivar in all 3 years, although all cultivars were susceptible (Table 3). Susceptibility of the cultivars planted for late blight observational purposes was relatively low, and some exhibited better resistance to late blight than the study's five entries. 'Red Brandywine' had the lowest late blight AUDPC values for both production systems in 2010, 'Defiant' was not affected by late blight in either production system in 2011, and 'Glacier' and 'Red Defender' had the fewest number of late blight infected tissues compared with other cultivars in the open-field plots in 2012 (data not shown).

Five isolates of $P$. infestans were recovered from affected plant tissues between 2010 and 2012. Results from the allozyme and genotype characterizations indicated that each isolate obtained was the clonal lineage US-11 ( $n=1$ each in 2010 and 2011; $n=3$ in 2012). The US-11 isolate recovered in 2011 had a variation at the simple sequence repeat (SSR) microsatellite locus PiG11, which could be a different allele $(155 / 155 \mathrm{bp})$ than what was detected in 2012 (131/155 bp) because all other SSR loci evaluated were identical (N. Grünwald, personal communication).

Physiological leaf roll was observed on all cultivars in all years, and plants were more severely affected in high-tunnel than in openfield plots. High tunnels contributed significantly $(P=0.034$ and $0.025)$ to increased severity of physiological leaf roll compared with open-field production in 2011 and 2012, respectively (Table 4). Severity of physiological leaf roll increased steadily throughout each growing season but, starting in mid-September, the new growth emerged unaffected and severity ratings decreased. Typi-
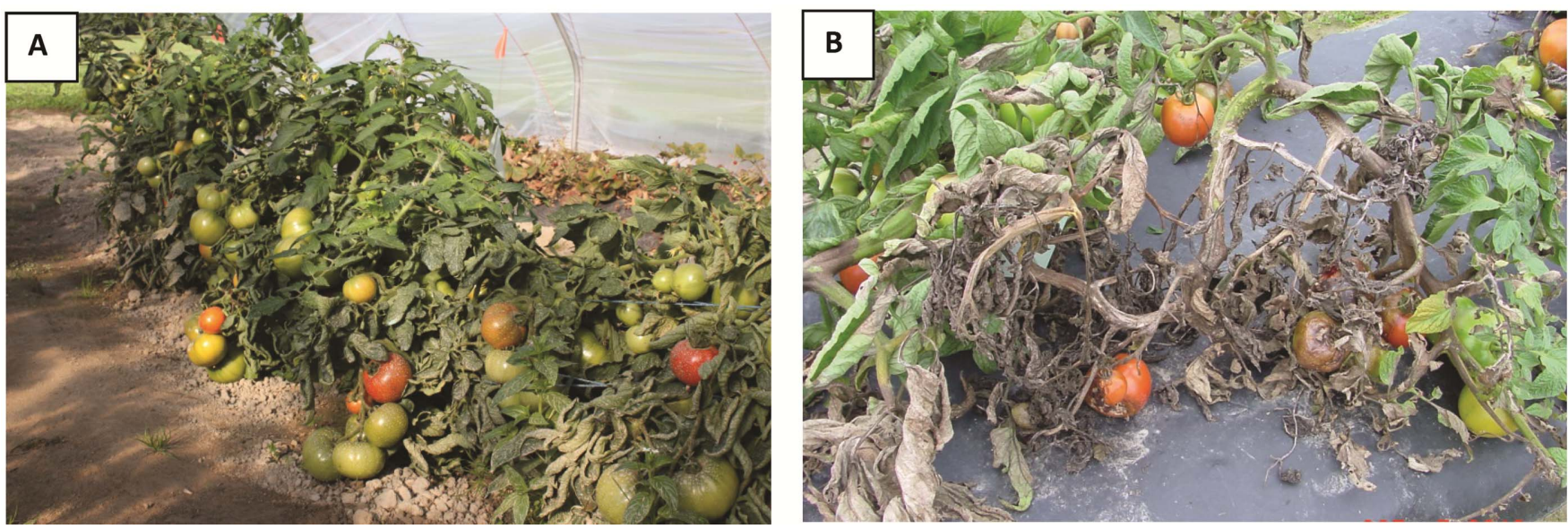

Fig. 1. Severity of late blight in A, high-tunnel plots on 28 September and B, open-field plots on 7 October 2010.

Table 3. Late blight assessments for tomato cultivars grown in high-tunnel (HT) and open-field (OF) production systems, 2010 to 2012

\begin{tabular}{|c|c|c|c|c|c|c|}
\hline \multirow[b]{3}{*}{ Variable } & & & \multicolumn{4}{|c|}{ Mean number of late blight infections across cultivars ${ }^{y}$} \\
\hline & \multicolumn{2}{|c|}{$2010^{\mathrm{z}}$} & \multicolumn{2}{|c|}{2011} & \multicolumn{2}{|c|}{2012} \\
\hline & Blight $(\%)$ & AUDPC & HT & OF & HT & $\mathbf{O F}$ \\
\hline \multicolumn{7}{|l|}{ Location } \\
\hline High tunnel & $0.002 \mathrm{a}$ & $0.02 \mathrm{a}$ & - & - & - & - \\
\hline Open field & $37.8 \mathrm{~b}$ & $321 \mathrm{~b}$ & - & - & - & - \\
\hline $\operatorname{LSD}(P=0.05)$ & 25.1 & 96.5 & - & - & - & - \\
\hline \multicolumn{7}{|l|}{ Cultivar } \\
\hline Celebrity & 22.5 & 159 & 1.8 & 5.5 & 1.8 & 16.8 \\
\hline Cherokee Purple & 15.0 & 128 & 0.3 & 4.8 & 6.0 & 4.8 \\
\hline Early Girl & 16.3 & 160 & 0.0 & 5.5 & 2.8 & 16.0 \\
\hline Oregon Spring & 28.1 & 211 & 0.0 & 25.0 & 3.8 & 30.8 \\
\hline Stupice & 12.5 & 145 & 1.3 & 8.0 & 6.5 & 14.3 \\
\hline $\operatorname{LSD}(P=0.05)$ & 7.9 & 89 & 2.2 & 19.8 & 5.5 & 29.0 \\
\hline
\end{tabular}

${ }^{\mathrm{y}}$ Mean number of infections rank transformed and analyzed nonparametrically using PROC GLM (SAS Institute Inc., Cary, NC); - indicates a significant interaction between production system and cultivar.

${ }^{\mathrm{z}}$ Final percent foliar late blight (Blight) and area under disease progress curve values (AUDPC) based on late blight ratings per plot; no significant interaction between production system and cultivar detected in 2010. Nontransformed percent foliar blight and AUDPC values presented; mean separation is for rank transformed data. Numbers within a column followed by the same letter are not significantly different $(P=0.05)$ as determined by Fisher's protected least significant difference (LSD). 
cally, physiological leaf roll was most severe during mid-August. AUDPC values for physiological leaf roll showed that Celebrity, Cherokee Purple, and Stupice were among the most susceptible each year but Oregon Spring was significantly $(P=<0.0001)$ less affected each year.

Environmental monitoring. Higher average air temperatures were recorded in the high tunnel than in the open field each year. Although seasonal air temperatures averaged 1 to $2^{\circ} \mathrm{C}$ greater in the high tunnels, on warm, sunny days the air temperature inside the high tunnels exceeded temperatures recorded in the open field by approximately 3 to $8^{\circ} \mathrm{C}$. Typically, average air temperature was greatest in both high-tunnel and open-field production systems in August. Percent physiological leaf roll was significantly $(P<0.05)$ and positively correlated ( $r$ value $=0.758$ to 0.908 ) with air temperature in all 3 years for both production systems (Table 5).

Leaf wetness duration was greatest early and late in the growing season, occurring in early June and starting again in mid-September, regardless of the production system. In 2012, accumulation of leaf wetness hours during July and August coincided with summer rains, accumulations that were apparent in the high tunnels especially. However, each year, total hours of accumulated leaf wetness was less in the high tunnels compared with the open fields (857 versus 1,060 in 2010, 598 versus 998 in 2011, and 885 versus 923 in 2012, respectively). Late blight significantly $(P=0.0439)$ and positively correlated $(r=0.889)$ with duration of leaf wetness in the open field in 2010 only (Table 5). Correlation analysis for late blight with the three environmental parameters could not be done in 2011 and 2012 due to the way late blight had to be measured by random removal of blighted tissues. For physiological leaf roll, there was a significant $(P<0.05)$ positive correlation $(r$ values $=$ 0.797 to 0.960 ) with leaf wetness each year for both high tunnels and the open field (Table 5).

High tunnels reduced relative humidity by approximately 1 to $5 \%$ compared with the open fields. In all 3 years, relative humidity for both production systems was greatest during July, ranging from 74 to $80 \%$ in the high tunnels and 77 to $85 \%$ in the open field. In the 2010 growing season, the open-field plots received 7 and $2 \mathrm{~cm}$ more precipitation and accumulated 62 and 137 more hours of leaf wetness than in 2011 and 2012, respectively. The most severe late blight outbreak occurred in 2010 in the open field, when $14 \mathrm{~cm}$ of precipitation and $1,060 \mathrm{~h}$ of leaf wetness were recorded from 3 June to 27 September. Late blight was detected early in 2012 (on 26 July), when summer rains $(1.5 \mathrm{~cm})$, high relative humidity $(88$ to $93 \%)$, and mild air temperatures $\left(13.5\right.$ to $\left.15.8^{\circ} \mathrm{C}\right)$ occurred. One week before late blight onset in 2012 , leaf wetness duration was

Table 4. Physiological leaf roll assessments on tomato cultivars grown in high-tunnel and open-field production systems, 2010 to 2012

\begin{tabular}{lccc}
\hline & \multicolumn{3}{c}{ AUDPC $^{\mathbf{y}}$} \\
\cline { 2 - 4 } Variable & $\mathbf{2 0 1 0}^{\mathbf{z}}$ & $\mathbf{2 0 1 1}^{\mathbf{z}}$ & $\mathbf{2 0 1 2}$ \\
\hline Location & & & \\
High tunnel & 2,081 & $2,460 \mathrm{~b}$ & $2,733 \mathrm{~b}$ \\
Open field & 1,783 & $1,719 \mathrm{a}$ & $2,248 \mathrm{a}$ \\
LSD $(P=0.05)$ & 487 & 421 & 371 \\
Cultivar & & & \\
Celebrity & $2,392 \mathrm{c}$ & $2,418 \mathrm{bc}$ & $2,528 \mathrm{~b}$ \\
Cherokee Purple & $1,986 \mathrm{~b}$ & $2,880 \mathrm{c}$ & $3,348 \mathrm{c}$ \\
Early Girl & $1,894 \mathrm{~b}$ & $2,097 \mathrm{~b}$ & $2,517 \mathrm{~b}$ \\
Oregon Spring & $867 \mathrm{a}$ & $592 \mathrm{a}$ & $1,507 \mathrm{a}$ \\
Stupice & $2,521 \mathrm{c}$ & $2,461 \mathrm{bc}$ & $2,552 \mathrm{~b}$ \\
LSD $(P=0.05)$ & 313 & 289 & 316 \\
\hline
\end{tabular}

y Area under disorder progress curve (AUDPC) values based on weekly visual ratings of subplot severity (0 to $100 \%$ ); no significant interaction between production system and cultivar detected any year. Numbers within a column followed by the same letter are not significantly different $(P=$ 0.05 ) as determined by least squares means.

${ }^{z}$ Data included in table extracted from previous reports for 2010 (25) and 2011 (28).
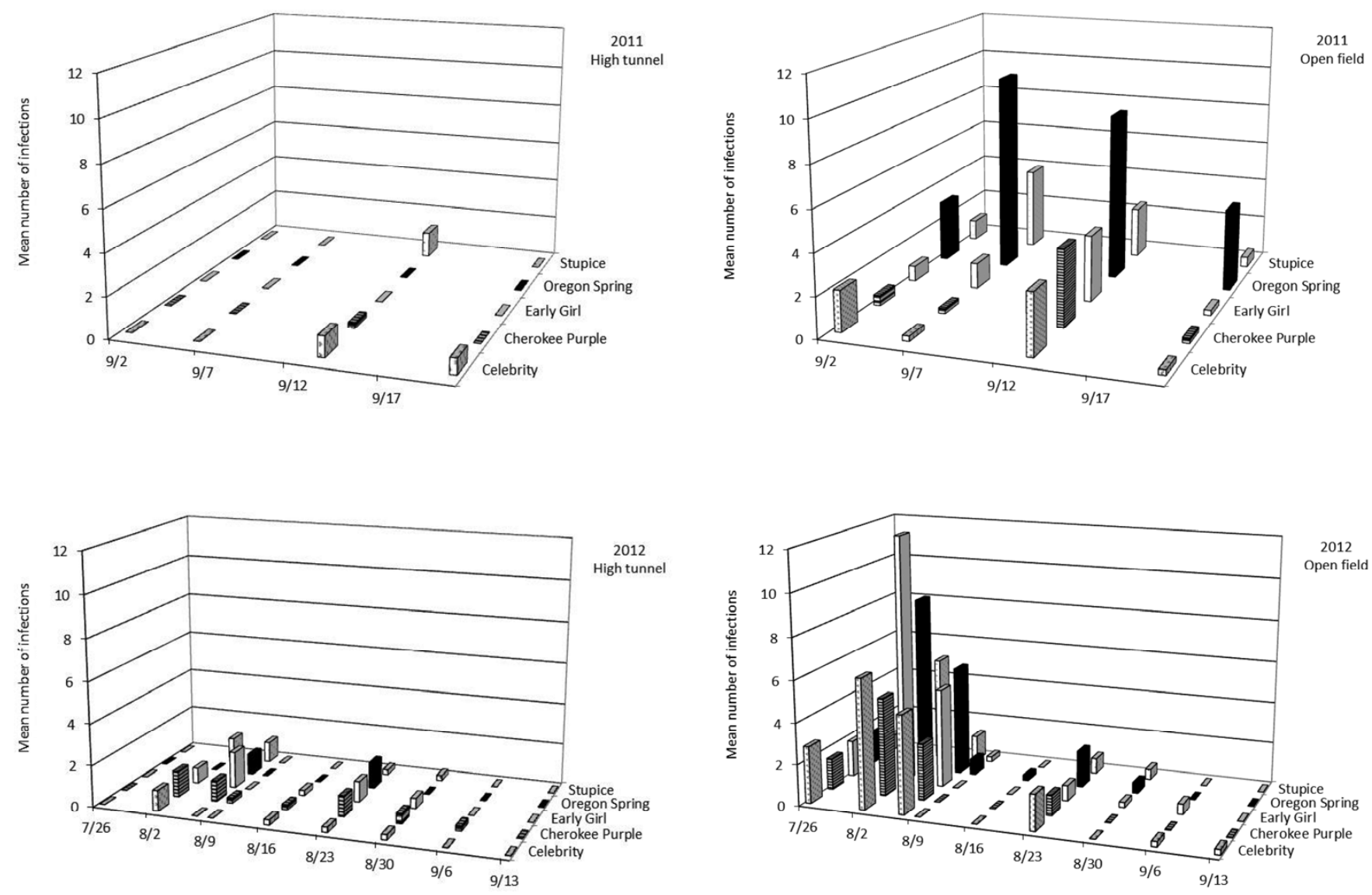

Fig. 2. Mean number of late blight infections detected and removed on tomato cultivars in high-tunnel and open-field plots, 2011 to 2012. 
longer in the high tunnel than in the open field, ranging from 0.25 to $7.75 \mathrm{~h}$ more per day. However, also during this time, air temperatures were 0.7 to $2.2^{\circ} \mathrm{C}$ higher and relative humidity consistently was 5 to $6 \%$ lower in the high tunnels than the open field. Sporulation by $P$. infestans was observed on affected plants when air temperatures were 13 to $19^{\circ} \mathrm{C}$, and these temperatures were common to both production systems. Late blight and physiological leaf roll did not correlate consistently with relative humidity in either production system in either year.

Tomato yield. Total fruit weight was significantly $(P<0.0001)$ greater in high tunnels than in the open field in 2010 (Table 6). Although there was a significant interaction between production system and cultivar in 2011 and 2012 due to cultivars ranking differently in yield, tomato yield always was greater in the high tunnels compared with the open field. Among cultivars, there was no significant difference in total fruit weight in 2010. However, in 2011, Cherokee Purple, Early Girl, and Stupice had significantly $(P=0.007)$ greater total yield than Celebrity in high tunnels and, in the open field, Oregon Spring and Stupice had significantly $(P=$ $<0.0001)$ greater total yield than the other cultivars. Although there were no significant differences in total yield among cultivars in high tunnels in 2012, Oregon Spring and Stupice again had significantly $(P<0.0001)$ higher yield than Celebrity, Cherokee Purple, and Early Girl in the open field.

The weight of total marketable fruit also was significantly $(P<$ $0.013)$ greater in high-tunnel compared with open-field production in 2010. Cherokee Purple had significantly $(P=0.003)$ lower marketable yield than the other cultivars. A significant interaction between production system and cultivar was detected in 2011 and 2012 due to cultivars ranking differently in the two production settings but, again, marketable yield always was greater in high tunnels than in the open field. Due to the use of a different marketing standard in 2011 and 2012, the overall values for marketable yield for both production systems were greater than in 2010 . Stupice had the greatest marketable yield in the open field in 2011 and $2012(P<0.0001$ and 0.0001 , respectively), while Early Girl

Table 5. Correlation analysis of percent late blight in 2010 and percent physiological leaf roll in 2010 to 2012 with leaf wetness, air temperature, and relative humidity in high-tunnel (HT) and open-field (OF) production systems ${ }^{\mathrm{z}}$

\begin{tabular}{|c|c|c|c|c|c|c|}
\hline \multirow[b]{3}{*}{ Year, disease, disorder } & \multicolumn{6}{|c|}{ Production system and environmental variable } \\
\hline & \multicolumn{2}{|c|}{ Leaf wetness } & \multicolumn{2}{|c|}{ Relative humidity } & \multicolumn{2}{|c|}{ Air temperature } \\
\hline & HT & $\mathbf{O F}$ & HT & OF & HT & OF \\
\hline \multicolumn{7}{|l|}{2010} \\
\hline HT late blight & $\begin{array}{l}r=0.564 \\
P=0.3224\end{array}$ & $\begin{array}{l}\text { NA } \\
\ldots\end{array}$ & $\begin{array}{l}r=0.359 \\
P=0.5528\end{array}$ & $\begin{array}{l}\text { NA } \\
\ldots\end{array}$ & $\begin{array}{l}r=-0.085 \\
P=0.8917\end{array}$ & $\begin{array}{l}\text { NA } \\
\ldots\end{array}$ \\
\hline OF late blight & $\begin{array}{l}\text { NA } \\
\ldots\end{array}$ & $\begin{array}{l}r=0.889 \\
P=0.0439\end{array}$ & $\begin{array}{l}\text { NA } \\
\ldots\end{array}$ & $\begin{array}{l}r=0.737 \\
P=0.1553\end{array}$ & $\begin{array}{l}\mathrm{NA} \\
\ldots\end{array}$ & $\begin{array}{l}r=0.575 \\
P=0.3104\end{array}$ \\
\hline HT leaf roll & $\begin{array}{l}r=0.797 \\
P=0.0178\end{array}$ & $\begin{array}{l}\mathrm{NA} \\
\ldots\end{array}$ & $\begin{array}{l}r=-0.103 \\
P=0.8075\end{array}$ & $\begin{array}{l}\text { NA } \\
\ldots\end{array}$ & $\begin{array}{l}r=0.758 \\
P=0.0294\end{array}$ & $\begin{array}{l}\text { NA } \\
\ldots\end{array}$ \\
\hline OF leaf roll & $\begin{array}{l}\text { NA } \\
\ldots\end{array}$ & $\begin{array}{l}r=0.907 \\
P=0.0019\end{array}$ & $\begin{array}{l}\text { NA } \\
\ldots\end{array}$ & $\begin{array}{l}r=0.478 \\
P=0.2306\end{array}$ & $\begin{array}{l}\text { NA } \\
\ldots\end{array}$ & $\begin{array}{l}r=0.863 \\
P=0.0057\end{array}$ \\
\hline \multicolumn{7}{|l|}{2011} \\
\hline HT leaf roll & $\begin{array}{l}r=0.868 \\
P=0.0113\end{array}$ & $\begin{array}{l}\text { NA } \\
\ldots\end{array}$ & $\begin{array}{l}r=0.766 \\
P=0.0446\end{array}$ & $\begin{array}{l}\text { NA } \\
\ldots\end{array}$ & $\begin{array}{l}r=0.814 \\
P=0.0259\end{array}$ & $\begin{array}{l}\text { NA } \\
\ldots\end{array}$ \\
\hline OF leaf roll & $\begin{array}{l}\text { NA } \\
\ldots\end{array}$ & $\begin{array}{l}r=0.925 \\
P=0.0028\end{array}$ & $\begin{array}{l}\text { NA } \\
\ldots\end{array}$ & $\begin{array}{l}r=0.450 \\
P=0.3112\end{array}$ & $\begin{array}{l}\text { NA } \\
\ldots\end{array}$ & $\begin{array}{l}r=0.897 \\
P=0.0061\end{array}$ \\
\hline 2012 & & & & & & \\
\hline HT leaf roll & $\begin{array}{l}r=0.952 \\
P<.0001\end{array}$ & $\begin{array}{l}\text { NA } \\
\ldots\end{array}$ & $\begin{array}{l}r=-0.730 \\
P=0.0108\end{array}$ & $\begin{array}{l}\text { NA } \\
\ldots\end{array}$ & $\begin{array}{l}r=0.908 \\
P=0.0001\end{array}$ & $\begin{array}{l}\text { NA } \\
\ldots\end{array}$ \\
\hline OF leaf roll & $\begin{array}{l}\text { NA } \\
\ldots\end{array}$ & $\begin{array}{l}r=0.960 \\
P<.0001\end{array}$ & $\begin{array}{l}\text { NA } \\
\ldots\end{array}$ & $\begin{array}{l}r=-0.844 \\
P=0.0011\end{array}$ & $\begin{array}{l}\text { NA } \\
\ldots\end{array}$ & $\begin{array}{l}r=0.861 \\
P=0.0007\end{array}$ \\
\hline
\end{tabular}

$\overline{\mathrm{z}}$ Percent data based on weekly severity ratings. Environmental data recorded at 15-min intervals using one Onset Hobo weather station and data logger (Onset Computer Corporation, Cape Cod, MA) for one HT and OF plot from 3 June to 27 September 2010, 31 May to 20 September 2011, and 30 May to 13 September 2012. NA = analysis not appropriate.

Table 6. Yield comparisons for tomato cultivars grown under high-tunnel (HT) and open-field (OF) production systems, 2010 to $2012^{\mathrm{t}}$

\begin{tabular}{|c|c|c|c|c|c|c|c|c|c|c|}
\hline \multirow[b]{3}{*}{ Variable } & \multicolumn{5}{|c|}{ Total yield $\left(\mathrm{t} \mathrm{ha}^{-1}\right)$} & \multicolumn{5}{|c|}{ Total marketable yield $\left(\mathrm{t} \mathrm{ha}^{-1}\right)^{\mathrm{u}}$} \\
\hline & \multirow[b]{2}{*}{$2010^{y}$} & \multicolumn{2}{|c|}{$2011^{\mathrm{v}}$} & \multicolumn{2}{|c|}{$2012^{v, w}$} & \multirow[b]{2}{*}{$2010^{z}$} & \multicolumn{2}{|c|}{$2011^{v, x}$} & \multicolumn{2}{|c|}{$2012^{v, x}$} \\
\hline & & HT & OF & HT & OF & & HT & OF & HT & OF \\
\hline \multicolumn{11}{|l|}{ Location } \\
\hline High tunnel & $35.0 \mathrm{a}$ & - & - & - & - & $4.9 \mathrm{a}$ & - & - & - & - \\
\hline Open field & $10.6 \mathrm{~b}$ & - & - & - & - & $0.6 \mathrm{~b}$ & - & - & - & - \\
\hline $\operatorname{LSD}(P=0.05)$ & 8.4 & - & - & - & - & 3.5 & - & - & - & - \\
\hline \multicolumn{11}{|l|}{ Cultivar } \\
\hline Celebrity & 19.3 & $29.6 \mathrm{c}$ & $6.7 \mathrm{~b}$ & 31.4 & $2.1 \mathrm{c}$ & $2.0 \mathrm{~b}$ & $13.5 \mathrm{c}$ & $2.4 \mathrm{~d}$ & $13.7 \mathrm{~cd}$ & $0.2 \mathrm{c}$ \\
\hline Cherokee Purple & 21.8 & $58.7 \mathrm{a}$ & $12.6 \mathrm{~b}$ & 29.8 & $6.2 \mathrm{~b}$ & $0.5 \mathrm{c}$ & $25.6 \mathrm{~b}$ & $3.0 \mathrm{~d}$ & $9.6 \mathrm{~d}$ & $1.6 \mathrm{~b}$ \\
\hline Early Girl & 21.2 & $48.6 \mathrm{ab}$ & $8.8 \mathrm{~b}$ & 29.4 & $4.1 \mathrm{~b}$ & $6.6 \mathrm{a}$ & $41.8 \mathrm{a}$ & $7.3 \mathrm{c}$ & $23.0 \mathrm{ab}$ & $2.3 \mathrm{~b}$ \\
\hline Oregon Spring & 25.8 & $43.6 \mathrm{bc}$ & $32.9 \mathrm{a}$ & 39.9 & $14.9 \mathrm{a}$ & $2.3 \mathrm{bc}$ & $19.6 \mathrm{bc}$ & $13.1 \mathrm{~b}$ & $17.2 \mathrm{bc}$ & $1.9 \mathrm{~b}$ \\
\hline Stupice & 26.1 & $54.2 \mathrm{ab}$ & $29.0 \mathrm{a}$ & 35.6 & $12.3 \mathrm{a}$ & $2.5 \mathrm{bc}$ & $51.5 \mathrm{a}$ & $26.4 \mathrm{a}$ & $32.4 \mathrm{a}$ & $10.0 \mathrm{a}$ \\
\hline $\operatorname{LSD}(P=0.05)$ & 13.3 & 14.1 & 9.0 & 10.8 & 3.7 & 2.8 & 11.2 & 5.5 & 9.7 & 2.8 \\
\hline
\end{tabular}

${ }^{\mathrm{t}}$ Numbers within a column followed by the same letter are not significantly different $(P=0.05)$ as determined by Fisher's protected least significant difference (LSD); - indicates a significant interaction between production system and cultivar was detected.

u Different marketable yield assessments were made in 2010 (USDA Grade 1) from 2011 and 2012 (USDA Grade 2).

${ }^{\vee}$ A significant interaction was detected between production system and cultivar in 2011 and 2012.

${ }^{\mathrm{w}}$ Nontransformed total yield values are presented; mean separation is for square root transformed data.

${ }^{\mathrm{x}}$ Nontransformed total yield values are presented; mean separation is for $\log _{10}$ transformed data.

${ }^{y}$ Nontransformed total yield values are presented; mean separation is for rank transformed data.

${ }^{\mathrm{z}}$ Nontransformed total yield values are presented; mean separation is for reciprocal transformed data. 
and Stupice produced the greatest marketable yields in the high tunnels the same years $(P<0.0001$ and $P=0.002$, respectively).

No trends between tomato yield and physiological leaf roll were observed. For example, Oregon Spring was significantly less affected by physiological leaf roll compared with all other cultivars in 2011 and 2012, and high total yields were recorded. However, Stupice, which was among the most susceptible of the cultivars in 2010 and 2011, had high total and marketable yields in both 2011 and 2012

\section{Discussion}

Late blight is the most serious disease problem in tomato production worldwide, and physiological leaf roll affects many tomato cultivars but is not well understood. This 3-year study evaluated five cultivars for both late blight and physiological leaf roll in hightunnel and open-field production systems. During each growing season, late blight and physiological leaf roll were observed but severity of these problems differed by production system. Secondary problems during the study only slightly affected plant health or marketability of fruit, and included blossom end rot (calcium deficiency), Botrytis fruit rot caused by Botrytis cinerea, tomato pith necrosis caused by Pseudomonas corrugata (49), and white mold caused by Sclerotinia sclerotiorum. US-11 was the genotype of Phytophthora infestans identified each year. Since 1999, US-11 (A1 mating type; mefenoxam resistant) has been isolated from infected tomato tissues in western Washington predominantly $(10,11,26)$. Gavino et al. (17) hypothesized that the US-11 clonal lineage of $P$. infestans is particularly fit when tomato are part of an agroecosystem.

High tunnels have been shown to reduce the severity of late blight on tomato in various regions of the world by excluding sporangia (early shelter and closed end walls) and providing less than optimal air temperature and relative humidity conditions for the growth of $P$. infestans $(29,31,36,55)$. The benefits of open-ended high tunnels for late blight management during this study included reduced need for protective fungicide applications in all years and delayed disease onset in 2010 and 2011. Across all 3 years, late blight was managed in high tunnels with 3 fungicide applications whereas open fields required 15 . Weekly protective fungicide applications are a common practice to control late blight during favorable weather but can increase production costs and potentially harm the environment. Organic tomato growers in the United States have experienced greater yield loss due to late blight than conventional growers because conventional growers have the option to use non-copper-based fungicides. Copper fungicide applications are effective for controlling late blight only if applied preventively $(41,54)$ but copper can build up in the soil over time $(56)$, leading to undesired effects on nontarget microbial, insect, and aquatic populations, including beneficial organisms, and may lead to copper toxicity $(6,54,56,68)$. In this study, copper-based fungicide applications were made. Specifically, in 2011, none were required to manage late blight in the high tunnels, yet six applications had to be made in the open field to obtain measurable yields.

The open-ended high-tunnel structures resulted in either lower final percent foliar blight and AUDPC values or fewer infected tissues compared with the open field-even without sanitation by rogueing as in 2010 or multiple fungicide applications as in 2011 and 2012. Although the progress of the late blight epidemics in 2011 and 2012 were altered deliberately by regular and frequent removal of infected plant tissues in order to avoid blighted fruit, comparison of disease incidence between high-tunnel and openfield production is valid because rogueing practices and times were identical each year for both systems. Additionally, high tunnels contributed to a delayed onset of late blight, which is an important disease control tactic due to the polycyclic nature of the disease (14). When occasional late blight lesions were observed in high tunnels, they were associated with plants near end openings where wind-driven rain may have entered, beneath damaged plastic where water may have dripped, or adjacent to side walls where plants overgrew and water condensed.
High tunnels can alter air temperature, leaf wetness, relative humidity, and precipitation, all factors known to affect the development of late blight on tomato $(2-4,24)$. Gundersen et al. (22) calculated lower disease severity values and recommended fewer fungicide applications for tomato grown in high-tunnel compared with open-field plots by using a late blight prediction software program, IPM-WISDOM (University of Wisconsin, Madison), based on historical precipitation, relative humidity, and temperature records. In this study, the combination of rain protection and polyethylene mulch with drip irrigation, which reduces evaporation, likely lowered the duration of leaf wetness within the high tunnel, with the end result of lower late blight incidence and severity relative to open-field production in all years. Plants grown under high tunnels accumulated fewer hours of leaf wetness each year, ranging from 38 to 400 fewer hours, compared with the open field. Reducing leaf wetness is important because zoospores of $P$. infestans require a water film to move and resist desiccation. Becktell et al. (3) demonstrated that $P$. infestans can become established on wet leaves of inoculated tomato plants within 2 to $6 \mathrm{~h}$ under optimal temperatures. The correlation analysis here demonstrated that plants in the open field exposed to additional hours of leaf wetness had greater percent late blight. However, in coastal areas such as western Washington, open-ended high tunnels can provide periods of excess leaf moisture, due to prolonged cool weather, and persistent, penetrating fogs. Therefore, cultural practices such as pruning and trellising to improve ventilation around plants still are needed for high-tunnel production. Some growers, organic and conventional, have had difficulty controlling late blight in high tunnels (13). Information about ventilation procedures and the types of end walls was not included in these reports, however. As a rule, foliar diseases can be managed, in part, by improving ventilation (32). If end walls are kept closed, high tunnels trap additional heat, reduce air flow, and raise relative humidity, similar to greenhouses $(3,32)$. If not managed properly, high tunnels, like greenhouses, can create a favorable environment for $P$. infestans.

The five cultivars evaluated in this study were susceptible to late blight in both production systems but differences in susceptibility could only be detected among cultivars grown in the open field. Oregon Spring was consistently the most susceptible cultivar whereas Defiant, a midseason-maturing cultivar used for late blight observational purposes in 2011, was the only cultivar in which late blight lesions were not observed in either production system. Where markets exist for cultivars that are susceptible to late blight, high tunnels may offer a way for growers to produce profitable yields.

Even though measures to reduce plant stress within the high tunnels were taken, such as venting the tunnels and using raised beds with black polyethylene mulch for uniform drip irrigation and soil drainage, physiological leaf roll was observed each year during the 3-year study. All cultivars, regardless of growth habit, developed physiological leaf roll in both production systems, but severity was typically greatest in mid-August. Also, severity between determinate and indeterminate types was similar each year. In this trial, all plants were pruned uniformly but pruning is a cultural practice that may be associated with this disorder (46). Future studies evaluating pruning methods or irrigation schedules may be beneficial for better understanding of physiological leaf roll in high-tunnel production. However, despite this disorder being more severe on plants in high-tunnel plots, total and marketable tomato yields were not affected. High-tunnel yields remained greater than yields obtained from the open-field plots in all 3 years. Also, the disorder did not appear to affect tomato yield across cultivars. This finding verifies for western Washington a previous report that physiological leaf roll does not affect yield (57).

Improved fruit yield and reduced late blight severity and fungicide use are good reasons to adopt high-tunnel systems for tomato production in western Washington. Galinato et al. (16) showed that high-tunnel production costs can be spread out over years because the structure and plastic covering are reusable, and returns can be high compared with open-field production in western Washington 
(15). This study demonstrates that well-managed, open-ended high tunnels can provide control for late blight in a region where annual outbreaks occur, and offer organic growers a new method for controlling this disease even under high disease pressure. In contrast, environmental conditions within high tunnels appeared to increase the severity of physiological leaf roll but this disorder did not impact tomato yield. Because other tomato diseases or disorders also may be favored by high-tunnel production, continued disease monitoring will be essential, especially in stationary tunnels where continuous cropping could increase the risk of other foliar and soilborne pathogens.

\section{Acknowledgments}

This study was part of a USDA SCRI-SREP grant award (number 200951181-05897). We thank J. Roozen for his contributions to this project, the Bill Fry Laboratory at Cornell University for $P$. infestans identification, and L. Porter and $\mathrm{D}$. Johnson for their critical review of this manuscript.

\section{Literature Cited}

1. Babadoost, M. 2011. Leaf mold (Fulvia fulva), a serious threat to high tunnel tomato production in Illinois. Acta Hortic. (ISHS) 914:93-96.

2. Beckerman, J. L. 2004. Disease management in high tunnels. Section 9 in: Minnesota High Tunnel Production Manual for Commercial Growers. Univ. Minn. Ext. Publ. M1218:1-10. [See Addendum]

3. Becktell, M. C., Daughtrey, M. L., and Fry, W. E. 2005a. Temperature and leaf wetness requirements for pathogen establishment, incubation period, and sporulation of Phytophthora infestans on Petunia $\times$ hybrida. Plant Dis. 89:975-979.

4. Becktell, M. C., Daughtrey, M. L., and Fry, W. E., 2005b. Epidemiology and management of petunia and tomato late blight in the greenhouse. Plant Dis. 89:1000-1008.

5. Berg, A. 1926. Tomato late blight and its relation to late blight of potato. Online. WV Agric. Exp. Stn. Bull. 205:1-33. http://ia600502.us.archive.org/ 6/items/tomatolateblight205berg/tomatolateblight205berg.pdf

6. Bünemann, E. K., Schwenke, G. D., and Van Zwieten, L. 2006. Impact of agricultural inputs on soil organisms-A review. Aust. J. Soil Res. 44:379406

7. Carey, E. E., Jett, L., Lamont, W. J., Jr., Nennich, T. T., Orzolek, M. D., and Williams, K. A. 2009. Horticultural crop production in high tunnels in the United States: A snapshot. HortTechnology 19:37-43.

8. Corbin, A.T., Miles, C., Cowan, J., Hayes, D., Moore-Kucera, J., and Inglis, D. 2013. Current and future prospects for biodegradable plastic mulch in certified organic production systems. eOrganic. Online publication. http:// www.extension.org/pages/67951

9. Cowan, J. 2013. The use of biodegradable mulch for tomato and broccoli production: crop yield and quality, mulch deterioration, and growers' perceptions. Ph.D. dissertation, Washington State University, Pullman.

10. Derie, M. L., and Inglis, D. A. 2001. Persistence of complex virulences in populations of Phytophthora infestans in western Washington. Phytopathology 91:606-612.

11. Dorrance, A. E., Inglis, D. A., Derie, M. L., Brown, C. R., Goodwin, S. B., Fry, W. E., and Deahl, K. L. 1999. Characterization of Phytophthora infestans populations in western Washington. Plant Dis. 83:423-428.

12. Erwin, D. C., and Ribeiro, O. K. 1996. Page 85 in: Phytophthora Diseases Worldwide. American Phytopathological Society, St. Paul, MN.

13. Fry, W. E., McGrath, M. T., Seaman, A., Zitter, T. A., McLeod, A., Daniels, G., Small, I., Myers, K., Everts, K., Gevens, A., Gugino, B. K., Johnson, S., Judelson, H., Ristaino, J., Roberts, P., Secor, G., Seebold, K., Snover-Clift, K., Wyenandt, A., Grünwald, N. J., and Smart, C. D. 2012. The 2009 late blight pandemic in eastern USA. APSnet Features. Online publication. http://www.apsnet.org/publications/apsnetfeatures/Pages/2009LateBlight.aspx

14. Fry, W. E., and Mizubuti, E. S. 1998. Potato late blight. Page 375 in: The Epidemiology of Plant Diseases. Kluwer Academic Publishers, Norwell, MA.

15. Galinato, S., and Miles, C. 2013. Economic profitability of growing lettuce and tomato in western Washington under high tunnel and open-field production systems. HortTechnology 23:453-461.

16. Galinato, S. P., Miles, C. A., and Ponnaluru, S. S. 2012. Cost estimates of producing high-tunnel tomatoes in western Washington. Washington State University Extension Fact Sheet FS090E. Online publication. http://cru.cahe.wsu.edu/CEPublications/FS090E/FS090E.pdf

17. Gavino, P. D., Smart, C. D., Sandrock, R.W., Miller, J. S., Hamm, P. B., Lee, T. Y., Davis, R. M., and Fry, W. E. 2000. Implications of sexual reproduction for Phytophthora infestans in the United States: Generation of an aggressive lineage. Plant Dis. 84:731-735.

18. Gent, M. P. N. 1991. High tunnels extend tomato and pepper production. Conn. Agric. Serv. Bull. 893:3-16. http://archive.org/details/hightunnelsexten00gent

19. Giacomelli, G. A. 2009. Engineering principles impacting high-tunnel environments. HortTechnology 19:30-33.

20. Goodwin, S. B., Schneider, R. E., and Fry, W. E. 1995. Use of cellulose- acetate electrophoresis for rapid identification of allozyme genotypes of Phytophthora infestans. Plant Dis. 79:1181-1185.

21. Goodwin, S. B., Smart, C. D., Sandrock, R. W., Deahl, K. L., Punja, Z. K., and Fry, W. E.1998. Genetic change within populations of Phytophthora in festans in the United States and Canada during 1994 to 1996: Role of migration and recombination. Phytopathology 88:939-949.

22. Gundersen, B., Inglis, D. A., and Miles, C. A. 2011. Control of late blight on tomato in western Washington using high tunnels. Poster presentation: 2011 Annual Meeting American Phytopathology Society Poster P-321.

23. Hu, C.-H., Perez, F. G., McLeod, A., Myers, K., Ivors, K., Secor, G., Roberts, P. D., Deahl, K. L., Fry, W. E., and Ristaino, J. B. 2012. Recent genotypes of Phytophthora infestans in the eastern United States reveal clonal populations and reappearance of mefenoxam sensitivity. Plant Dis. 96:13231330.

24. Hyre, R. A. 1955. Three methods of forecasting late blight of potato and tomato in northeastern United States. Am. Potato J. 32:362-371.

25. Inglis, D. A. 2011. Evaluation of physiological leaf roll on tomato cultivars in a high tunnel production system, 2010. Plant Dis. Manage. Rep. 5:V072.

26. Inglis, D. A., Gundersen, B., and Derie, M. 2001. Evaluation of tomato germplasm for resistance to late blight, 2000. Biol. Cult. Tests Control Plant Dis. 16:PT77.

27. Inglis, D. A., Gundersen, B., Ludy, R. L., and Powelson, M. L. 1998. Results of the 1997 North American late blight fungicide trial. (Abstr.) Am. J. Potato Res. 75:279.

28. Inglis, D. A., Gundersen, B., Miles, C., Roozen, J., Cowan, J., Powell, M., and Miles, C. 2012. Evaluation of physiological leaf roll on tomato cultivars in a high tunnel production system, 2011. Plant Dis. Manage. Rep. 6:V155.

29. Inglis, D. A., Gundersen, B., Miles, C., Roozen, J., Wallace, R., Wszelaki, A., and Walters, T. 2011. Evaluation of late blight on tomato cultivars grown in high tunnel vs. open field plots, 2010. Plant Dis. Manage. Rep. 5:V071.

30. Inglis, D. A., Gunderson, B., Miles, C., Roozen, J., Wallace, R., Wszelaki, A., and Walters, T. 2011. Evaluation of gray mold and Verticillium wilt on strawberry cultivars grown in high tunnel vs. open field plots, 2010. Plant Dis. Manage. Rep. 5:SMF047.

31. Inglis, D. A., Gunderson, B., Miles, C., Walters, T., and Roozen, J. 2009. Control of late blight caused by Phytophthora infestans on tomato cultivars using a high tunnel system, 2008. Plant Dis. Manage. Rep. 3:V057.

32. Jarvis, W. R. 1989. Managing diseases in greenhouse crops. Plant Dis 73:190-194.

33. Klonsky, K. 2012. Comparison of production costs and resource use for organic and conventional production systems. Am. J. Agric. Econ. 94:314321. doi:10.1093/ajae/aar102

34. Kinet, J. M., and Peet, M. M. 1999. Tomato. Page 230 in: The Physiology of Vegetable Crops. CABI Publishing, New York.

35. Kirk, R. E. 1982. Fundamental assumptions in analysis of variance. Pages 83-84 in: Experimental Design. C. D. Laughton and M. E. Hill, eds. Brooks/Cole Publishing, Monterey, CA

36. Kumar, R., and Srivastava, B. K. 1998. Effect of low plastic tunnels on the incidence of late blight of tomato. Crop Res. 15:279-280.

37. Lamont, W. J., Jr. 1993. Plastic mulches for the production of vegetable crops. HortTechnology 3:35-39.

38. Lamont, W. J., Jr. 2009. Overview of the use of high tunnels worldwide. HortTechnology 19:25-29.

39. Lees, A. K., Wattier, R., Shaw, D. S, Sullivan, L., Williams, N. A., and Cooke, D. E. L. 2006. Novel microsatellite markers for the analysis of Phytophthora infestans populations. Plant Pathol. 55:311-319.

40. Legard, D. E., Lee, T. Y., and Fry. W. E. 1995. Pathogenic specialization in Phytophthora infestans: Aggressiveness on tomato. Phytopathology 85:1356-1361.

41. McGrath, M. T. 2009. Managing late blight in organically-produced tomato Cornell Univ. Vegetable MD. Online publication. http://vegetablemdonline ppath.cornell.edu/NewsArticles/Tom_LB_OrganicMgt10.pdf

42. McMoran, D. 2012. 2011 Skagit County Agriculture Statistics. WSU Skagit County Ext. Online publication. http://skagit.wsu.edu/Agriculture/

43. Merk, H. L., Ashrafi, H., and Foolad, M. R. 2012. Selective genotyping to identify late blight resistance genes in an accession of the wild species Solanum pimpinellifolium. Euphytica 187:63-75.

44. Nowaki, M., Foolad, M. R., Nowakowska. M., and Kozik, E. U. 2012. Potato and tomato late blight caused by Phytophthora infestans: An overview of pathology and resistance breeding. Plant Dis. 96:4-17.

45. NRCS. 2010. Web soil survey. Soil Survey Staff, Natural Resources Conservation Service, United States Department of Agriculture. Online publication. http://websoilsurvey.nrcs.usda.gov/

46. Pacific Northwest Extension Publication. 2011. Physiological leaf roll of tomato factsheet. Online publication. http://cru.cahe.wsu.edu/CEPubli cations/PNW616/PNW616.pdf

47. Pittenger, D. R., Garrison, N. F., Geisel, P. M., Unruh, C. L. 2005. Growing tomatoes in the home garden. Univ. Calif. Davis Veg. Res. Inf. Center, UC ANR Publ. 8159

48. Powell, M., Cowan, J., Miles, C., and Inglis, D. A. 2013. Effect of a high tunnel, organic cropping system on lettuce diseases in western Washington. Plant Health Prog. Online publication. doi:10.1094/PHP-2013-0922-01-RS

49. Powell, M., Miles, C. A., Humann, J. L., Schroeder, B. K., and Inglis, D. A 
2013. First report of tomato pith necrosis (Pseudomonas corrugata Roberts \& Scarlett) on tomato (Solanum lycopersicum Mill) in Washington. Plant Dis. 97:1381. Online publication. doi.org/10.1094/PDIS-03-13-0265-PDN

50. Rader, H. B., and Karlsson, M. G. 2006. Northern field production of leaf and romaine lettuce using a high tunnel. HortTechnology 16:649-654.

51. Randhawa K. S.1990. Field vegetable production in certain multiple cropping patterns in relation to different times of sowing in Punjab (India). Pages 77-84. in: VI Symp. Timing of Field Prod. Veg. B. Booij, and P. H. M. Dekker, eds. Acta Hortic. (ISHS) 267.

52. Reeve, J., and Drost, D. 2012. Yields and soil quality under transitional organic high tunnel tomatoes. HortScience 47:38-44.

53. Satterthwaite, F. E. 1946. An approximate distribution of estimates of variance components. Biometr. Bull. 2:110-114.

54. Stone, A., and Baker, B. 2010. Organic management of late blight of potato and tomato with copper products. eXtension.org 18351. Online publication.

55. Tumwine, J., Frinking, H. D., and Jeger, M. J. 2002. Integrating cultural control methods for tomato late blight (Phytophthora infestans) in Uganda. Ann. Appl. Biol. 141:225-236.

56. Van-Zwieten, L., Merrington, G., and Van-Zwieten, M. 2004. Review of impacts on soil biota caused by copper residues from fungicide application. In: SuperSoil 2004: 3rd Aust. N. Z. Soils Conf. University of Sydney, Sydney, Australia.

57. Verma, P. 2009. Tomato. Page 137 in: Physiological Disorders of Vegetable Crops. Alfa Beta Technical Solutions, Pratap Naga Housing Board, Sanganer, Jaipur, India.

58. Wangsomboondee, T., Groves, C. T., Shoemaker, P. B., Cubeta, M. A., and Ristaino, J. B. 2002. Phytophthora infestans populations from tomato and potato in North Carolina differ in genetic diversity and structure. Phytopathology 92:1189-1195.

59. Waterer, D. 2003. Yields and economics of high tunnels for production of warm-season vegetable crops. HortTechnology 13:339-343.

60. Wells, O. S., and Loy, J. B. 1993. Rowcovers and high tunnels enhance crop production in the northeastern United States. HortTechnology 3:92-95.

61. Wien, H. C. 2009. Microenvironmental variations within the high tunnel. HortScience 44:235-238.

62. Wien, H. C., and Pritts, M. P. 2009. Use of high tunnels in the Northeastern USA: Adaptation to cold climates. Pages 55-59 in: Proc. IS on Prot. Cult. Mild Winter Climate. Acta Hortic. (ISHS) 807.

63. Wildung, D., Nennich, T., and Johnson, P. 2012. Tomatoes. Section Crops In: Minnesota High Tunnel Production Manual for Commercial Growers 2nd ed. Univ. Minn. Ext. Publ. 120-129. Online publication. http://high tunnels.cfans.umn.edu/minnesota-high-tunnel-production-manual/

64. Wittwer, S. H. 1993. World-wide use of plastics in horticultural production HortTechnology 3:6-19.

65. Woltz, S. S. 1968. Influence of light intensity and photosynthate export from leaves on physiological leaf roll of tomatoes. Proc. Fla. State Hortic. Soc. 81:208-211.

66. Wright, J., Nennich, T., Krause, N., Wildung, D., and Zilliox, L. 2007. High tunnel trellising. Section 6b in: Minnesota High Tunnel Production Manua for Commercial Growers. Univ. Minn. Ext. M1218. Online publication.

67. Xiao, C. L., Chandler, C. K., Price, J. F., Duval, J. R., Mertely, J. C., and Legard, D. E. 2001. Comparison of epidemics of Botrytis fruit rot and powdery mildew of strawberry in large plastic tunnel and field production systems. Plant Dis. 85:901-909.

68. Xiong, Z.-T., and Wang, H. 2005. Copper toxicity and bioaccumulation in Chinese cabbage (Brassica pekinensis Rupr.). Environ. Toxicol. 20:188194.

\section{Addendum}

Literature citation 2 has been edited with a new author and is now available as: Gugine, B. 2012. Plant diseases in high tunnels: Their pathology and control. In Disease Management, Minnesota High Tunnel Production Manual for Commercial Growers, 2nd ed. Univ. Minn. Ext. Publ. 78-88. Online publication. http://hightunnels.cfans.umn.edu/minnesota-high-tunnel-production-manual/ 